\title{
PRESTIŻ, TRADYCJA, WŁADZA - MIT O TROJAŃSKIM POCHODZENIU WE FRANCUSKIEJ HISTORIOGRAFII PRZEDOŚWIECENIOWEJ (REKONESANS BADAWCZY)*
}

\author{
Joanna Orzeł
}

http://orcid.org/0000-0001-8816-5157

Uniwersytet Łódzki

\section{ABSTRACT \\ PRESTIGE, TRADITION, POWER: TROJAN ORIGIN MYTH IN FRENCH PRE-ENLIGHTENMENT HISTORIOGRAPHY (RECONNAISSANCE RESEARCH)}

The beginnings of a nation or country occupy a special position in the mentality of every society. As medieval France searched for its roots in mythological and biblical events, the French attempted to prove their Troyan origins, as Troy was one of the most popular motives at the time. This article turns to Jan Assmann's concept of cultural memory to describe how in the early modern period this myth was changed and adapted to current needs. In France the Trojan myth served as an argument backing the independence of the French nation, and was constructed in opposition to the descent from the Gauls, who were conquered by the Romans. In addition, it was a tool of foreign policy (against England, the papacy and the Holy Roman Empire) and in internal politics.

Keywords: cultural memory, origin myth, Trojan War, French historiography, early modern period.

Słowa kluczowe: pamięć kulturowa, mit pochodzenia, wojna trojańska, historiografia francuska, historia wczesnonowożytna.

\footnotetext{
*Artykuł powstał w ramach badań przeprowadzonych dzięki dotacji celowej Wydziału Filozoficzno-Historycznego Uniwersytetu Łódzkiego nr B1611400001362.02. Kwerenda została uzupełniona podczas pobytu w Londynie sfinansowanego ze stypendium Fundacji z Brzezia Lanckorońskich.
} 
L'histoire, c'est du vrai qui devient faux. Le mythe, c'est du faux qui devient vrai.

Jean Cocteau

Badacze od pokoleń zajmują się mitami etnogenetycznymi (fundacyjnymi) między innymi z powodu ich uniwersalności - nie tylko uniwersalności mitów, lecz także tego, że można je analizować, korzystając z różnych metodologii. Przykładowo: W artykule napisanym kilka lat temu przez Annę Zawadzką mit pochodzenia Francuzów stanowił pretekst do badań nad stereotypowym postrzeganiem innych ${ }^{1}$. W niniejszym tekście opieram się na teorii pamięci kulturowej Jana Assmanna. Według niej mit ,jest historią założycielską, którą opowiada się, aby wyjaśnić teraźniejszość z perspektywy prapoczątku”2. Poszczególne państwa, chcąc wyjaśnić nazwy plemion, społeczeństw, krajów, usankcjonować strukturę władzy, zasięg terytorialny współczesnego organizmu państwowego czy nazewnictwo poszczególnych miast (ze stolicą jako miejscem prymarnym), kreowały mity pochodzenia. Joseph Rio twierdzi wręcz, że żadne społeczeństwo nie może istnieć bez historii i bez jego fundatora trzeba je zatem wymyślić ${ }^{3}$. Mity zaś są o wiele trwalsze niż prawda historyczna ${ }^{4}$, stąd tak duża ich popularność nawet dzisiaj.

W dobie średniowiecza $\mathrm{w}$ kreowaniu jak najdawniejszych dziejów państw pomagał Stary Testament. Francuzi twierdzili, że pochodzą od Jafeta, a właściwie od jego syna Gomera, który zajął zachodnie tereny Europy, zwłaszcza Galię. Sankcjonowało to ich dominację w tej części Starego Kontynentu. Dodatkowo potomstwo Jafetowe zostało przeznaczone do rządzenia, co legitymizowało władzę francuskich monarchów.

Drugą inspiracją dla twórców opowieści o najdawniejszych dziejach państw były zabytki piśmiennictwa greckiego i rzymskiego antyku - zarówno dzieła stricte historyczne, jak i literatura piękna. Przez stulecia nie podważano autorytetu starożytnych pisarzy. Należało więc zespolić te dwie tradycje - świecką i sakralną̧. W ten sposób na poziomie narracji mitycznej dokonywało się połączenie kultury grecko-rzymskiej $\mathrm{z}$ chrześcijaństwem.

1 A. Zawadzka, Mit etnogeniczny jako źródto $w$ studiach nad stereotypem. Mity o pochodzeniu Gallów [w:] Grecy, Rzymianie i ich sąsiedzi, red. K. Nawotka, M. Pawlak, współpraca A. Paluchowski, A. Wojciechowska, Wrocław 2007, s. 279-293.

2 J. Assmann, Pamięć kulturowa. Pismo, zapamiętywanie i polityczna tożsamość w cywilizacjach starożytnych, thum. A. Kryczyńska-P ham, red. R. Traba, Warszawa 2008, s. 68. Różnorodne znaczenie pojęcia „mit” i analiza wachlarza terminów z nim związanych w: B. Szacka, Czas przeszły-pamięć - mit, Warszawa 2004.

3 J. Rio, Mythes fondateurs de la Bretagne. Aux origines de la celtomanie, Rennes 2000, s. 23.

4 C.-G. Dubois, Celtes et Gaulois au XVI siècle, le développement littéraire d'un mythe nationaliste, Paris 1972, s. 11.

5 Szerzej: G. Huppert, The Idea of Perfect History: Historical Erudition and Historical Philosophy in Renaissance France, Chicago-London 1970, s. 25-28; K. Pomian, Przeszłość jako przedmiot wiary. Historia i filozofia w myśli średniowiecza, wyd. 2 rozszerzone, Warszawa 2009, s. 28 i n. 
Już w średniowieczu część krajów europejskich poszukiwała swoich korzeni w najdawniejszych czasach. Jednym z miejsc pamięci, do których się odwoływano, była mitologiczna (ale, jak się okaże, również mityczna) Troja, przez niemieckiego historyka Gerta Melville'a nazwana wręcz „kolebką Europy”. Za stworzenie historii zapewniającej identyfikację i legitymizację państw oraz ich władców szukających konotacji z antycznym miastem odpowiada Wergiliusz, twórca Eneidy ${ }^{7}$, w której występują protoplaści przyszłych państw i narodów. Jej główny bohater - Eneasz to uciekinier spod Troi, uznawany za założyciela Rzymu (choć był fundatorem Lawinium wchłoniętego następnie przez Rzym ${ }^{8}$. Doradca króla trojańskiego Priama - Antenor - miał założyć Padwę ${ }^{9}$ Kolejni Trojańczycy: Frygant, Turgot i Francjon, zawędrowali aż do doliny Dunaju w Europie Środkowej, gdzie się rozdzielili. Frygant trafił na Półwysep Bałkański i stał się przodkiem Macedończyków, Turgot został ojcem Turków, Ostrogotów, później Wizygotów, Duńczyków i Normanów, a Francjon - Franków ${ }^{10}$. Mamy więc do czynienia z prawdziwą „Trojomanią"

Opowieść o trojańskim pochodzeniu Francuzów była popularna przede wszystkim w historiografii średniowiecznej, następnie wczesnonowożytnej - głównie do końca XVII wieku. Tematyka ta powróciła w wieku XIX, co nie znaczy, że w XVIII stuleciu nie odwoływano się do tego mitu. W niniejszym artykule zostaną zaprezentowane ustalenia badaczy dotyczące głównie piśmiennictwa francuskiego z XV-XVII wieku. Jako że koncept o trojańskim pochodzeniu Francuzów nie pojawił się w okresie odrodzenia ad hoc, konieczne jest odwołanie do wieków średnich.

$\mathrm{W}$ średniowiecznych kronikach ${ }^{12}$ - nie wdając się w szczegóły różnych wersji opowieści - dominują stwierdzenia, że pierwszym władcą Franków był Priam. Wraz z 12000 mężczyzn ocalałych z wojny trojańskiej przepłynął przez Morze Azowskie

6 G. Melville, Troja: Die integrative Wiege europäischer Mächte im ausgehenden Mittelalter [w:] Europa 1500. Integrationsprozesse im Widerstreit: Staaten, Regionen, Personenverbände, Christenheit, hrsg. v. F. Seibt, W. Eberhard, Stuttgart 1987, s. 427-429.

M.-B. Bruguière, Mythes de fondation et mission de la France : la légende troyenne [w:] L'influence de l'antiquité sur la pensée politique européenne (XVI-XXème siècles), dir. par et préf. M. Ganzen, Aix-en-Provence 1996, s. 55.

8 Por. analizę mitu o Romulusie autorstwa Alexandre'a Grandazziego z odniesieniem do współczesności: A. Grandazzi, La Troie rêvée des Romains : quelles leçons pour l'Europe contemporaine? [w:] Le mythes de fondation et l'Europe, dir. B. Bernabé, O. Camy, Dijon 2013, s. 37-53.

9 Lub Wenecję. Por. A. B os sua t, Les origines troyennes : leur rôle dans la littérature historique au XV siècle, „Annales de Normandie” 1958, $8^{\mathrm{e}}$ année, nº 2, s. 189.

10 Ibidem.

11 J. Rio, op. cit., s. 27.

12 Przede wszystkim w Historia Francorum tzw. Fredegara (ok. 660) i w anonimowym Liber historiae Francorum (ok. 727). Analiza mitu o trojańskim pochodzeniu Francuzów w historiografii średniowiecznej zwłaszcza w: K. Wulf, Troja - Metamorphosen eines Mythos. Französische, englische und italienische Überlieferungen des 12. Jahrhunderts im Vergleich, Berlin 2009, passim; K. Pomian, Przeszłość jako przedmiot wiary, s. 29-45 (gdzie przywołano ok. 50 źródeł z okresu od VII do XIV w., w którym opowieść ta się pojawiła); J. Pysiak, Pogańska przeszłość Franków w świetle kilku kronik francuskich z czasów Filipa Augusta i Ludwika Świętego, „Kwartalnik Historyczny” R. 110, 2003, nr 1, passim; R.E. Asher, National Myth in Renaissance France: Francus, Samothes and the Druids, Edinburgh 1993, s. 9-15; J. Ri o, op. cit., s. 28-32; Ch. Gre11, Guerres généalogiques et identités nationales : la France et l'Europe, „Revista de Historiografía” 2011, № 15, s. 78-79. 
i następnie Donem dotarł na tereny Panonii. Osiedlili się oni nad Dunajem, założyli miasto Sykambrię (w której dopatrywano się dzisiejszego Budapesztu ${ }^{13}$ ) i przez wiele lat prowadzili spokojny żywot. Cesarz rzymski Walentynian ${ }^{14}$ miał ich nazwać Frankami od słowa féroce - oznaczającego osobę dziką, okrutną. Nie godząc się na płacenie podatków dla Rzymu oraz w wyniku wielu krwawych bitew (w których poległ między innymi Priam), Frankowie uciekli na tereny niemieckie. Tam pokonali rzymskie legiony wysłane przez cesarza Teodozjusza, dzięki czemu zyskali sławę odważnych i śmiałych wojowników ${ }^{15}$. Na terenach niemieckich doszło do przekazania władzy w ręce potomka Priama - Francjona (inaczej Priama młodszego lub Antenora - w zależności od źródła), bratanka Eneasza ${ }^{16}$. Następnie Francjon powierzył rządy Markomirowi i przybył do Galii. Jego syn Faramund (rzadziej zwany Faramondem) został pierwszym królem Franków i protoplastą Merowingów (481-751) ${ }^{17}$. Jednym z kolejnych władców (być może wnukiem Faramunda) miał być Chlodwig ${ }^{18}$. Stąd już tylko krok od przekazu mitycznego do rzeczywistości historycznej. Legalnymi następcami Merowingów i Karolingów (753-987) byli Kapetyngowie (987-1792) ${ }^{19}$.

W dobie średniowiecza taki właśnie przekaz i ciągłość związków genealogicznych dawały zakorzenienie w historii, budując państwową tożsamość Francji. Mit trojański dodawał splendoru, prestiżu, potwierdzał więzy krwi z Rzymianami i dowodził prawa do posiadania części ziem dawnego imperium rzymskiego. Henryk Samsonowicz wysuwa jeszcze jedną ciekawą tezę:

Poszukiwanie rodowodu ludów tworzących nowe wspólnoty państwowe na gruzach Imperium Romanum lub na jego obrzeżach wiązało się z wprowadzaniem swojej przeszłości w ramy niekiedy dość przypadkowej wiedzy o „dziejach prawdziwych”, to jest starych, spisanych, nawiązujących do funkcjonującej aż w głąb czasów nowożytnych tęsknoty do państwa doskonałego, za jakie uważano cesarstwo rzymskie ${ }^{20}$.

13 Por. ustalenia Alexandre'a Eckhardta na temat Sykambrii w historiografii francuskiej okresu średniowiecza i w XVI w.: A. Eckhardt, Sicambria, capitale légendaire des Français en Hongrie [w:] De Sicambria a Sans-Souci. Histoires et légendes franco-hongroises, Paris 1953, s. 11-51, wcześniej publikowane w: „Revue des Études Hongroises” 1928, vol. 6, s. 166-197.

14 Niestety kronikarze nie precyzowali, o którego cesarza rzymskiego chodziło: Walentyniana I (363-375) czy jego syna Walentyniana II (375-392).

15 A. Bossuat, op. cit., s. 189.

16 M. Pinsard, Nos ancêtres les Francs, [b.m.w.] 2013, s. 28.

17 Data nie jest jednoznaczna - wspomina się m.in. o 413, 417, 418, 419, 420 r. Por. J. Ko o p man s, À l'ombre de Pharamond : la royauté élective, „Cahiers de Recherches Médiévales et Humanistes” 2010, $\mathrm{n}^{\circ} 20$, s. 135.

18 O przystosowaniu pogańskiego mitu do religii chrześcijańskiej i panowania Chlodwiga zob. M.-B. Bruguière, op. cit., s. 58-60. Szerzej na temat religijnych motywów w budowaniu tożsamości narodu francuskiego: M. Yardeni, Enquêtes sur l'identité de la «nation France », de la Renaissance aux Lumières, Seyssel 2004, passim.

19 S. Citron, La construction du mythe national [w:] Histoire de France, mythes et réalités. Quelle place pour les peuples et les minorités? Quelle place pour l'Europe?, dir. S. Citron, Ch. Guy on varc' 'h, Y. Plass eraud, Toulouse 1995, s. 20; P. Moraw ski, Mit o trojańskim pochodzeniu Franków w historiografii średniowiecznej Francji, „Przegląd Humanistyczny” R. 51, 2007, nr 5, s. 65.

20 H. Sams onowicz, Mit ,początku” w oczach historyka, „Przegląd Humanistyczny” 1996, nr 1, s. 48 . 
A zatem także Francja - skoro w świetle kronik i tradycji miała takie samo pochodzenie jak Wieczne Miasto - była spadkobierczynią cesarstwa rzymskiego ${ }^{21}$. W średniowieczu historia Troi i Rzymu to swego rodzaju okazja do porównania porządku moralnego czy politycznego ${ }^{22}$. Wzorowano się na tych dwóch miastach, wznosząc nową Troję czy nowy Rzym. Jedna różnica jest jednak szczególnie widoczna w odwołaniach do mitycznych siedzib - z Troi wyszli założyciele wielu narodów europejskich $^{23}$, można ją zatem uznać za ważniejszą niż Rzym.

W XIV wieku do opowieści o francuskich prapoczątkach zostały dodane ważne szczegóły dotyczące przestrzeni ówczesnej Francji. Raoul de Presles (1316-1382), doradca króla Karola V (1364-1380), uzupełnił opowiadanie o pochodzeniu Francuzów. Według niego w 396 roku Francja miała zostać nazwana na cześć Francjona - wnuka Priama, a Lutecja stała się Paryżem na cześć Parysa - porywacza Heleny trojańskiej ${ }^{24}$. Autor ujawnił także genezę ustroju. Frankowie, dotychczas żyjący pod rządami książąt, pragnęli mieć króla - stąd się wziął Faramund, a następnie kolejni monarchowie aż do pierwszego chrześcijańskiego króla francuskiego Chlodwiga. Mityczna opowieść wyjaśniła nazwy państwa i stolicy, a dodatkowo usankcjonowała monarchię jako ustrój wywodzący się z prapoczątków Francji. Dzięki tej legendzie Francja zyskiwała historyczną przeszłość, która legitymizowała współczesne rządy.

Takie początki narodu były według francuskiej badaczki Colette Beaune szlachetne, dostojne, znamienite, wręcz idealne, co pozwalało budować pozycję władców, monarchii i państwa. Płynąca w żyłach Francuzów krew trojańska miała być najlepszą krwią świata, zapewniającą doskonałe cnoty, które uzasadniały wyjątkowe miejsce Francji pod koniec epoki średniowiecza ${ }^{25}$. Równie ważne okazało się wykorzystywanie mitycznej opowieści jako argumentu w walce politycznej, zwłaszcza w polityce zagranicznej ${ }^{26}$.

Walezjusze (1328-1589) i Burbonowie (1589-1792) mieli powody, by potwierdzać swoje trojańskie pochodzenie - od czasów średniowiecznych dworscy kronikarze ukazywali ich jako bezpośrednich i legalnych spadkobierców herosów epoki

21 M. Foucault, Wyktad z 11 lutego $1976 r$. [w:] idem, Trzeba bronić spoleczeństwa. Wyklady w Collège de France, 1976, thum. M. Kow alsk a, Warszawa 1998, s. 120.

22 M. Gosman, Alain Chartier : le mythe romain et le pouvoir royal français [w:] Entre fiction et histoire : Troie et Rome au Moyen Age, éds. E. B a umgartner, L. Harf-Lan cner, Paris 1997, s. 163.

${ }^{23}$ Za przykład może tu posłużyć Brutus (Bryton) - fundator Anglii. Spośród najważniejszych publikacji na ten temat warto przywołać: A. Adolph, Brutus of Troy and the Quest for the Ancestry of the British, Barnsley 2015; R.F. Brinkley, Arthurian Legend in the Seventeenth Century, London 1967; T.D. Kendrick, British Antiquity, New York-London 1970; A. Branny, Trojanie i król Artur w angielskiej świadomości historycznej do XVIII wieku, „Historyka. Studia Metodologiczne” 1986, t. 16, s. 3-20. Mitowi etnogenezy angielskiej (brytyjskiej) w historiografii wczesnonowożytnej zostanie poświęcony osobny artyku1.

24 Ph. Desan, Nationalism and History in France during the Renaissance, ,Rinascimento. Rivista dell'Instituto Nazionale di Studi sul Rinascimento", seconda serie, vol. XXIV, Firenze 1984, s. 272.

${ }_{25}$ C. Beaune, L'utilisation politique du mythe des origines troyennes en France à la fin du Moyen Âge [w:] Lectures médiévales de Virgile. Actes du colloque de Rome (25-28 octobre 1982), Rome 1985, s. 336 .

26 Taka funkcja mitu trojańskiego została przeanalizowania przez C. Beaune do 1450 r.: ibidem, s. 336-350. 
początków ${ }^{27}$. Zauważano jednak, że należy wystrzegać się sytuacji takiej, w jakiej znalazł się Hugo Kapet (987-996). Nie był on spadkobiercą trojańskich przodków w linii prostej, uzurpował sobie władzę, a kolejni przedstawiciele dynastii Kapetyngów wiązali się z rodem królewskim dzięki ożenkom. Taki sposób przejęcia władzy uznawano za niebezpieczny, bo dający argument do objęcia rządów we Francji Anglikom, zwłaszcza Lancasterom.

Po śmierci ostatniego przedstawiciela dynastii Kapetyngów - Karola IV Pięknego w 1328 roku - angielski król Edward III (syn Edwarda II i księżniczki Joanny Francuskiej) rościł sobie prawo do korony francuskiej. Była to jedna z przyczyn wojny stuletniej (1337-1453), która z walki o sukcesję między Walezjuszami a Plantagenetami szybko zmieniła się w wojnę między Francuzami a Anglikami. Przeciwko tym drugim wytoczono wówczas argumenty w postaci mitu o trojańskim pochodzeniu. Francuzi powoływali się na niego, dowodząc, że to do Walezjuszów przynależą Normandia czy Gujenna. Do tych ziem jednak prawo rościli sobie także Plantageneci i Lancasterowie ${ }^{28}$. Francuscy kronikarze przypominali więc, że północna Francja należała do Walezjuszów z powodu zajęcia tego regionu przez Francjona, ich przodka, w prapoczątkach państwa ${ }^{29}$. W czasie wojny stuletniej, w 1418 roku, Anglicy zajęli Paryż, co historyk Robert Blondel (1380-1460) porównał do zdobycia Troi przez Greków $^{30}$. W XV wieku Francuzi uznawali opowieść o trojańskich początkach za ważny argument na rzecz jedności terytorialnej, dlatego stwierdzali, że ich terytorium jest okupowane przez Plantagenetów. W stuleciu tym mit trojański wciąż dostarczał polemistom argumentów historycznych uznawanych za niepodważalne, służących do walki z największymi przeciwnikami - Anglikami ${ }^{31}$. Okres wojny stuletniej to dla Francji czas konsolidacji państwowej, jednoczącej nie tylko francuskie terytorium, lecz także społeczeństwo ${ }^{32}$.

Mit trojański wykorzystywano także jako argument w polityce dynastycznej. W połowie XV wieku opowieść o pochodzeniu Francuzów przywoływano jako element sojuszu z Węgrami zawiązanego przeciwko Habsburgom. Symbolem owego przymierza stały się zaślubiny króla Czech i Węgier Władysława II Jagiellończyka (1490-1516) z Anną de Foix-Candale (1484-1506) w 1502 roku. Małżeństwo to miało potwierdzać polityczną współpracę dynastii jagiellońskiej z Ludwikiem XII (1498-1515). Siostrzenicą matki nowej królowej Węgier i Czech była bowiem żona francuskiego monarchy - Anna Bretońska (1477-1514) ${ }^{33}$. Przypominano wówczas mityczną Sykambrię, którą utożsamiano z Budą. Twierdzono zatem, że Francuzi w osobie Anny de Foix-Candale - wracali do swych korzeni.

27 J. Pysiak, op. cit., s. 9; G. Huppert, The Idea..., s. 73.

28 A. Bossuat, op. cit., s. 188, 194-196.

29 Ph. Desan, op. cit., s. 270.

30 C. Beaune, Naissance de la nation France, Paris 1985, s. 40.

31 A. Bossuat, op. cit., s. 192.

32 Szerzej w: J. Kowalski, A. i M. Loba, J. Prokop, Dzieje kultury francuskiej, Warszawa 2007, s. 184-187.

33 C. Beaune, Naissance de la nation..., s. 45. 
Francji zależało również na podkreśleniu niezależności od starożytnych Rzymian, uwypukleniu tezy, że to Francuzi są najstarszym i najbardziej szlachetnym narodem. Ukazywanie hegemonii francuskiego narodu było widoczne w czasach panowania Karola Wielkiego (768-814) i dynastii Franków ${ }^{34}$. Potem mit wykorzystywano do podbojów ziem włoskich, do rywalizacji z Habsburgami. Claude-Gilbert Dubois zauważa z pewną przesadą, że nacjonalizm i ksenofobia odgrywały wówczas taką samą rolę jak później chęć zdobycia potęgi imperialnej ${ }^{35}$. Badacz ten konstatuje, że w XVI wieku istniał antagonizm władzy, jednak wszyscy żyli nostalgią za jednością: zarówno Francja, jak i Państwo Kościelne czy Święte Cesarstwo Rzymskie. Każdy jednak walczył o swoją niezależność. Państwo francuskie, przeciwstawiając się cesarstwu i (coraz częściej prowadzącemu realistyczną politykę) papiestwu, musiało wykorzystać argumenty historyczne, zatem prezentować się jako niezależne od Rzymu w przeszłości. Galia nie była więc opisywana jako rzymska kolonia: „Francja musiała się stać rodzajem nowego Rzymu - nowego, czyli niezależnego, ale jednak Rzymu. Absolutyzm króla miał tu takie samo znaczenie jak w samym Rzymie" ${ }^{36}$. Należało zatem pominąć tradycję rzymską, rzymskie przekazy, literaturę antyczną, całą spuściznę ukazującą Galię jako kolonię Rzymu ${ }^{37}$. W okresie renesansu ukazywano Germanów, Galów czy Słowian jako ofiary antycznej ekspansji rzymskiej ${ }^{38}$.

Coraz większy sceptycyzm widoczny w dziełach epoki renesansu, nowe podejście do źródeł antycznych, ponowne ich odczytywanie i interpretowanie uderzało jednak we francuski mit państwowy ${ }^{39}$. Pojawiły się wątpliwości natury źródłowej, krytykowano zwłaszcza zbyt dużą przepaść chronologiczną między Francjonem a Markomirem czy brak przekazów antycznych potwierdzających istnienie tych po$\operatorname{staci}^{40}$. Mimo to rzadko decydowano się na radykalne przeciwstawienie się trojańskiemu mitowi ${ }^{41}$, ponieważ między 1200 a 1500 rokiem pełnił on zbyt wiele ważnych dla państwa funkcji: stał się gwarantem prestiżu, jedności etnicznej narodu, obrony w wojnie z Anglią i argumentem przeciwko papiestwu i cesarstwu ${ }^{42}$.

W kronikach renesansowych zmieniono wizję początków Francuzów - ich przodkami nie byli Trojańczycy, a plemiona germańskie Franków ${ }^{43}$. Wówczas rozpoczęła się debata, która trwała przez wiele wieków. Zadawano sobie pytanie: czy przodkami

34 P. Morawski, op. cit., s. 60.

35 C.-G. Dubois, Celtes et Gaulois..., s. 18.

36 M. Foucault, op. cit., s. 121.

Ibidem, s. 120.

38 P.J. Geary, The Myth of Nations: The Medieval Origins of Europe, Princeton 2002, s. 19.

39 M.-B. Bruguière, op. cit., s. 73.

40 C. Beaune, L'utilisation politique..., s. 332.

41 Chociażby Pierre Desgros ok. 1461 r. czy Jean Candida i Jean de Legonissa za panowania Karola VIII (1470-1498), szerzej: C. B e aune, L'utilisation politique..., s. 332, przyp. 4.

42 Ibidem, s. 332; M. Foucault, op. cit., s. 121.

43 J. Poucet, L'origine troyenne des peuples d'Occident au Moyen Âge et à la Renaissance. Un exemple de parenté imaginaire et d'idéologie politique, „Les Études Classiques” 2004, t. 72, s. 79. 
są Frankowie czy Galowie ${ }^{44}$, a jeśli ci drudzy, to jakie mają pochodzenie ${ }^{45}$ ? W piśmiennictwie Galowie pojawiali się coraz wyraźniej. Mieli nad Trojańczykami tę przewagę, że ich dzieje były udokumentowane od czasów antycznych. Przed historiografami pojawiło się zadanie udowodnienia, że i Galowie są Frankami ${ }^{46}$. Należało tego dowieść w celu zachowania spójności przekazu i potwierdzenia jedności narodowej - w tym państwowej i terytorialnej. Najłatwiejszym i polubownym rozwiązaniem okazało się przypisanie Galom pochodzenia trojańskiego. Uznano więc, że część antycznych Franków mieszkających w Panonii wyruszyła do Galii wcześniej niż reszta na tereny niemieckie i potem - już na terytorium francuskim - połączyła się z pozostałymi. Około 1500 roku jednak i ta wersja została podana w wątpliwość. Innym wyjaśnieniem było stwierdzenie, że Galowie osiedleni na terenach dzisiejszej Francji ruszyli do Panonii i stamtąd „sprowadzili” Franków do ojczyzny, by wspólnymi siłami walczyć przeciwko Rzymianom. Na rzecz tej koncepcji przywoływano argument, że w czasach antycznych Galowie i Frankowie nie prowadzili walk bratobójczych, tylko przeciwko wspólnemu wrogowi, czyli Rzymowi ${ }^{47}$. Państwowy mit o trojańskim pochodzeniu wciąż był potrzebny do potwierdzenia jedności kraju (bez ukazywania różnic między regionami) i solidarności grup społecznych opartej na pokrewieństwie. Galów uznano zatem za swego rodzaju kuzynów Trojańczyków - dzięki temu wzmacniano mit o ich prawie do terytorium francuskiego, jako że Galowie mieli tu być pierwszymi osiedleńcami ${ }^{48}$. Faramund zaś stał się symbolem jedności dwóch ludów żyjących na terenie Francji: Franków i Galów. Teoria ta rozwijała się od początku XVI wieku.

W czasach francuskiego renesansu (czyli od zakończenia wojny stuletniej w 1453 r. do śmierci Michela de Montaigne’a w 1592 r.) najważniejsi myśliciele stworzyli odpowiedni język opisujący pochodzenie, mowę, kulturę Francuzów odmienne od reszty Europejczyków ${ }^{49}$. Wśród badaczy pojawił się nawet postulat, wedle którego nacjonalizm narodził się właśnie wtedy. Philippe Desan twierdzi, że w XV wieku francuska świadomość narodowa wciąż pozostawała słaba, a jej wzmocnienie było zadaniem pisarzy szesnastowiecznych ${ }^{50}$. Badacz ten wyodrębnił pięć powiązanych ze sobą idei (mitycznych i legendarnych), które w XV-XVI wieku posłużyły do wypracowania fundamentów idei francuskiego narodu. Wśród nich

${ }_{44}$ O funkcjonowaniu mitu galijskiego w kulturze XVI w. i jego potrzebie politycznej zob. C.-G. Dubois, "Nos ancêtres les Gaulois ». Le développement d'un mythe des origines nationales au $16^{e}$ siècle [w:] Nos ancêtres les Gaulois, dir. P. Viallaneix, J. Ehrard, Clermont-Ferrand 1982, s. 19-27. Szerzej o micie galijskim w kulturze nowożytnej, także XIX-wiecznej Francji, w innych artykułach w przywołanej pracy zbiorowej.

45 Najszersza analiza tej debaty w: C. Be aune, Naissance de la nation..., rozdz. Trojani aut Galli?, s. $15-54$.

46 Eadem, L'utilisation politique..., s. 334.

47 Ibidem, s. 334-335.

48 M.-B. Bruguière, op. cit., s. 68.

49 Ph. Desan, op. cit., s. 262.

50 Ibidem, s. 279. 
wymienił: prawo salickie, legendę trojańską, powstanie Paryża, mit galijski, pochodzenie od galijskiego Herkulesa ${ }^{51}$.

W nowożytność francuska historiografia weszła z kanoniczną wręcz wersją opowieści o trojańskim pochodzeniu Francuzów. Znajduje się ona między innymi w pracy Nicole'a Gilles'a (zm. 1503) Les Chroniques et Annales de France depuis la destruction de Troye, jusque au Roy Louis unziesme. Robert Gaguin (1433-1501) $\mathrm{w}$ Compendium de Francorum origine et gentis (,Kompendium o pochodzeniu i dziejach Franków") z 1495 roku zakwestionował z kolei opowieść o trojańskim pochodzeniu ${ }^{52}$. Dzięki dziełu Gaguina mit trojański we francuskiej polityce zagranicznej pełnił dwie funkcje: z jednej strony wymierzony był przeciwko Anglikom - Plantagenetom, z drugiej - zapewniał supremację nad Italią ${ }^{53}$. W dobie renesansu przyczyny popularności opowieści mitycznej okazały się zatem takie same jak w poprzednich wiekach. Dzięki mitowi o przodkach spod Troi Francuzi mogli się zrównać z Rzymianami. Ci pierwsi - jak twierdzono - mieli wręcz pierwszeństwo nad kulturą łacińską dzięki trojańskim konotacjom - w końcu kultura łacińska powstała o wiele później niż grecka. Gaguin bardzo skrótowo i jakby niechętnie zaczął swoje dzieło od mitu pochodzenia z uwagi na świadomość braku źródeł, jednak nie skłoniło go to do krytyki historycznej czy odrzucenia dotychczasowej wersji opowieści etnogenetycznej ${ }^{54}$. Historyk albo nie przeprowadził należycie krytyki źródeł, albo nie chciał odrzucić wielowiekowej tradycji. Trojańska legenda była zbyt potrzebna - umacniała jedność narodową przez wspólną dumę francuską i jednocześnie przez ustanowienie niepodważalnych praw monarchy francuskiego do królestwa ${ }^{55}$.

O pozycję nadwornego historiografa na dworze francuskim Gaguin rywalizował z weneckim historykiem Paolem Emiliem (1455-1529), który w dziele De rebus gestis Francorum (1516) uznał, że Frankowie są germańskim ludem (choć postać Faramunda jako ich pierwszego króla nie została zakwestionowana ${ }^{56}$. Kolejni historycy zaczęli już nie tylko głosić taki pogląd, ale wręcz go udowadniać57. Krytyka przyszła przede wszystkim ze strony niemieckiego humanisty Beatusa Rhenanusa (1485-1547). W Rerum Germanicarum libri tres (1531) uznał on - na podstawie dzieł antycznych uczonych - że po podbiciu Galów ich ziemie zostały zasiedlone przez ludy germańskie.

W XVI stuleciu mit o Galach jako przodkach Francuzów szybko zyskiwał na popularności. Badacze zwracają uwagę, że mit galijski różnił się od trojańskiego przede wszystkim nastawieniem na konkrety. „Nowych” antycznych przodków opisano

51 Ibidem, s. 262-263. O stworzeniu postaci galijskiego Herkulesa szerzej: ibidem, s. 284-288; B.L.O. Richter, Trojan or Merovingians? The Renaissance Debate over the Historical Origins of France [w:] Mèlanges à la mémoire de Franco Simone, vol. 4, Geneva 1983, s. 115.

52 A.F. Grabski, Dzieje historiografii, Poznań 2011, s. 186.

53 Ph. Desan, op. cit., s. 276.

${ }_{54}$ G. Huppert, The Idea..., s. 76.

55 M. Schmidt-Chazan, Histoire et sentiment national chez Robert Gaguin [w:] B. Guenée, Le Métier d'historien au Moyen Age, Paris 1977, s. 244, cyt. za: Ph. Des an, op. cit., s. 272.

${ }_{56}$ G. Huppert, The Idea..., s. 76-77; K. Pomian, Przeszłość jako przedmiot wiedzy, wyd. 2 poprawione, Warszawa 2010, s. 65.

57 Por. G. Huppert, The Idea..., s. 77 i n. 
ze szczegółami dotyczącymi ubioru czy biżuterii, by odróżnić ich od innych dawnych ludów. W ten sposób mit galijski wypierał mit trojański ${ }^{58}$.

W dziełach historycznych odnajdujemy także próby pogodzenia obu odmiennych relacji. Jean Le Maire de Belges (1473-1524) połączył mit trojański z galijskim. W jego przekazie Galowie i Frankowie są Trojańczykami ${ }^{59}$. Między 1509 a 1549 rokiem opublikowano sześć wydań jego Les illustrations de Gaule et singularitez de Troye... Były one nieprzychylne i pogardliwe wobec Italii ${ }^{60}$. Praca ukazała się pod koniec panowania Ludwika XII (1498-1515), który kontynuował wojny na Półwyspie Apenińskim. Notabene jego następca Franciszek I Walezjusz (1515-1547) także marzył o podbiciu ziem włoskich. Monarcha ten nie został wybrany na tron Świętego Cesarstwa Rzymskiego - władcą został Karol V Habsburg (1519-1556), syn zmarłego niedawno Maksymiliana (1508-1519), przez co Francja w dużej mierze została otoczona przez posiadłości habsburskie. W pierwszej połowie XVI wieku francuska monarchia wciąż toczyła wojny o hegemonię z Habsburgami, zatem mit o trojańskich przodkach znakomicie nadawał się do walki propagandowej. Aby tradycja i związany z nią prestiż wciąż były po stronie Francuzów, Le Maire de Belges dążył do udowodnienia przeszłości Francuzów niezależnej od Rzymu i Aten, pragnął wykazać, że współczesne mu francuskie zwycięstwa na włoskim terytorium są kontynuacją podbojów starożytnych Galów. Ważniejsze jednak dla niego stało się ukazanie „marszu cywilizacji” przez Europę centralną, z przystankiem w Sykambrii, w celu złączenia się Trojańczyków (Franków) z Galami. Grecja i Rzym są w jego opisie zaledwie aktorami przyglądającymi się ekspansji cywilizacji celtycko-trojańskiej ${ }^{61}$.

Jean Le Maire de Belges zaczął swą opowieść od Noego jako ojca wszystkich ludzi, bez względu na narodowość, bez wskazywania, która z nacji powinna mieć jakiekolwiek przywileje. Taki uniwersalizm miał się z kolei przekładać na harmonię świata cywilizacji zachodniej i równość nacji ${ }^{62}$. Według Claude'a-Gilberta Dubois również Francjon jest przykładem mitu uniwersalnego, który - w długim trwaniu - przyniósł owoce także w postaci Karola Wielkiego - w wymiarze religijnym mitycznego ojca Europy ${ }^{63}$. Wszystkie te motywy w relacji Le Maire'a de Belges to opór przed współczesną dominacją papieża i kultury włoskiej, symbolizowanej przez Rzym.

Kwestie rzymskie pojawiły się także w dziele Jeana Boucheta Anciennes et modernes Genealogies des roys de France (1527). Pisarz rozpoczął genealogię królów francuskich od Faramunda, ale - co równie ważne - zrównał go z Romulusem ${ }^{64}$. Równość tych dwóch antycznych założycieli miała być symboliczną próbą pogodzenia państw. Według kronikarza nikt nie podawał w wątpliwość tej teorii, trwały

58 Ph. Desan, op. cit., s. 280.

59 C. Beaune, Naissance de la nation..., s. 22.

60 Ph. Desan, op. cit., s. 281.

61 C.-G. Dubois, Celtes et Gaulois..., s. 35.

62 Ibidem, s. 37. Por. R. Bizzoc chi, Genealogie incredibili. Scritti di storia nell'Europa moderna, Bologna 1995, s. 32 i n.

63 C.-G. Dubois, Celtes et Gaulois..., s. 37.

${ }^{64}$ B.L.O. Richter, op. cit., s. 118. 
jednak spory na temat etymologii pojęcia „Frankowie” - czy pochodziło ono od cesarza Walentyniana, czy od imienia Francjona (według Boucheta - „syna Hektora spod Troi") ${ }^{65}$. W opisie Sykambrii - założonej przez Francjona, ale zniszczonej i przeniesionej do Galii - szesnastowieczny pisarz francuski powoływał się na dzieła Tacyta $^{66}$. Któż zaś sprzeniewierzyłby się autorytetowi antycznego uczonego? Bouchet zgadzał się na podział Franków na - jak ich nazwał - galijskich i germańskich ${ }^{67}$. Ponownie więc mamy do czynienia z próbą harmonijnego pogodzenia dwóch mitów etnogenetycznych.

Część badaczy uznaje Le Maire’a de Belges za prekursora gallizmu, jednak apologetą takiej wizji początków Francji był Guillaume Postel (1510-1581). W swoim dziele o wiele mówiącym tytule: Apologie de la Gaule contre les malevoles escrivains, qui d'icelle on mal ou négligemment escript, et en après les très anciens Droictz du peuple gallique et de ses princes (1552) przytaczał argumenty potwierdzające jego teorie na temat francuskiej etnogenezy, opierające się na porównaniach językowych (zgodnie z jego lingwistycznymi zainteresowaniami i licznymi studiami w tym zakresie). W hebrajskim słowie „galuyah” (oznaczającym oddzielenie się wody i ziemi z chaosu) doszukał się słowa „Gal” - tak zatem nazywali się według niego pierwsi ludzie ${ }^{68}$. „Dowód” ten miał potwierdzać nie tylko prestiż, lecz także władzę na terytorium Portu-GAL-ii oraz GAL-icji, co dowodziło podbojów Galów w tych częściach Europy ${ }^{69}$. Legitymizacja przestrzeni wpływów królów francuskich nastąpiła ponownie dzięki tradycji - tym razem obejmowała jednak nie rejony północne, jak w czasach średniowiecznych, ale południowe.

Według Claude’a-Gilberta Dubois Guillaume Postel miał największy wpływ na uformowanie i rozwój mitu narodowego. W jego wersji znalazły się wszystkie podstawowe elementy zintegrowane $\mathrm{w}$ jeden system, tworzący wyjaśnienie historii uniwersalnej $^{70}$, w tym genealogię biblijną. Biblijnym przodkiem Francuzów w dziele Postela był oczywiście Jafet, jego potomkowie byli zatem przeznaczeni do władania Europą Zachodnią, a zwłaszcza Galią. Zostali obdarzeni religijną sankcją do

65 Ibidem, s. 119.

66 Ibidem.

67 Ibidem; R.E. A sher, op. cit., s. 66.

68 Ph. Desan, op. cit., s. 281-282; C.-G. Dubois, Celtes et Gaulois..., s. 63. Interesujące jest to, że sto lat później w Rzeczypospolitej Obojga Narodów dowodów ,językowych” na to, że Scytowie byli pierwszym ludem na ziemi, poszukiwał ksiądz Wojciech Dembołęcki (Dębołecki). Jak widać, nie tylko motywy, lecz także konstrukcja mitów fundacyjnych były zbliżone we wczesnonowożytnej Europie. W. Dębołęcki (Dembołęcki), O tym, że najdawniejsze w Europie jest królestwo polskie, a język słowieński pierwotnym językiem świata [w:] Filozofia i myśl społeczna XVII wieku, cz. 1, wybór, oprac., wstęp Z. Ogonow sk i, Warszawa 1979, s. 145-164. Por. J. Orzeł, Historia-tradycja-mit w pamięci kulturowej szlachty Rzeczypospolitej w XVI-XVIII wieku, Warszawa 2016, s. 249-250. O poszukiwaniach potwierdzeń językowych (tym razem z greki), mających świadczyć o trojańskim pochodzeniu Francuzów, zob. P. Cohen, In Search of the Trojan Origins of French: The Uses of History in the Elevation of the Vernacular in Early Modern France [w:] Fantasies of Troy: Classical Tales and the Social Imaginary in Medieval and Early Modern Europe, eds. A. Shepard, S.D. Powe11, Toronto 2004, s. 63-77.

69 Ph. Desan, op. cit., s. 282; C.-G. Dubois, Celtes et Gaulois..., s. 69.

70 C.-G. Dubois, Celtes et Gaulois..., s. 54. 
dominacji w tej części Starego Kontynentu, bo ich przodkowie - Galowie - mieli otrzymać prawa od samego Boga ${ }^{71}$.

Problem Galów i Franków rozwiązał Postel (podobnie jak Le Maire de Belges) polubownie - ukazując alians między obydwoma plemionami w przeszłości. Chciał w ten sposób skłonić Germanów-Niemców do zgody, wytrącając im z rąk argument za prowadzeniem wojny z Francją. Według Dubois cały system Postela jest jednak narodowy i imperialny ${ }^{72}$. W wizji początków państwa pisarz ten znalazł fundament historyczny i racjonalny na potwierdzenie znaczenia monarchii absolutnej i prawa boskiego, a w konsekwencji te dwa mity - jak twierdzi Dubois - zrodziły monarchię absolutną, potem zaś rewolucję ${ }^{73}$.

W wydanych w 1560 roku Des recherches de la France Étienne Pasquier (15291615) uznał, że nie ma sensu się kłócić i próbować dopasować mitu do historii, wymyślając kolejne konotacje (nawet biblijne). Stwierdził, że opowieść o trojańskich korzeniach jest najprawdopodobniej tylko ,piękną bajką”. Nie wspominał o Trojańczykach czy Frankach, ale zaczął od Galów ${ }^{74}$, bo ci byli poświadczeni źródłowo, między innymi przez Juliusza Cezara. Według Pasquiera historia Francji rozpoczęła się wtedy, gdy pojawili się kronikarze. To nowe spojrzenie na historiografię, początki większego niż dotychczas krytycyzmu wobec opowieści mitycznych ${ }^{75}$. Zapominano wówczas o trojańskim Francjonie i przenoszono początki francuskiej historii do Faramunda - pierwszego króla ${ }^{76}$.

Krytyka trojańskich korzeni Francji spowodowała, że utwór Francjada Pierre'a Ronsarda (1524-1585) z 1572 roku nie spotkał się z żywym odzewem ${ }^{77}$. Dzieło literata, mające być epopeją narodową na miarę Iliady i Odysei Homera oraz Eneidy Wergiliusza, powstało w bardzo okrojonej wersji. Miało rozsławić pierwszego władcę Franków - syna Hektora, bohatera trojańskiego. W eposie (mimo że stworzone zostały zaledwie fragmenty) widoczne są motywy prognostyczne - Francjonowi miały się ukazać postaci Karola Młota czy Pepina Małego. Ponadto przepowiadano założenie Paryża - fundacja przyszłej stolicy państwa stanowiła powtarzający się motyw w mitach etnogenetycznych ${ }^{78}$. Warto zwrócić uwagę, że Ronsard nie był jedynym poetą chcącym rozsławić pierwszego władcę Franków. Podobne „Francjady” stworzyli Pierre de Laudun (1575-1629) czy Jean Godard (1564-1630) ${ }^{79}$.

71 Ibidem, s. 69 i n., 77. Por. B.L.O. Richter, op. cit., s. 121.

72 C.-G. Dubois, Celtes et Gaulois..., s. 83.

73 Ibidem, s. 84.

74 G. Huppert, The Idea..., s. 35.

75 Ibidem, s. 36.

76 Ibidem. Więcej o tym dziele Pasquiera zob. ibidem, s. 28-71. Por. wcześniejszy artykuł G. Hupperta: Naissance de l'histoire en France : les « Recherches » d'Estienne Pasquier, „Annales. Economies, Sociétés, Civilisations" 1968, 23 année, no 1, s. 69-105.

77 Szerzej o dziele Ronsarda w: R.E. A sher, op. cit., s. 112-153.

78 Tylko dla przykładu: Brutus (Bryton) - ojciec założyciel Anglików - ufundował Nową Troję, przemianowaną potem na Londyn; Lech na swoją siedzibę wybrał Gniezno, a Palemon (zwany początkowo Wilią lub Wiliusem) - fundator litewski - Wilno.

79 R.E. Asher, s. 133-148. 
Społeczeństwo oczekiwało jednak dzieła na miarę Wergiliuszowego poematu. W 1578 roku powstał utwór La Galliade Guya Le Fèvre'a de La Boderie (15411598). Odniósł on niebywały sukces. Autor we wstępie wyjaśnił, że słowo „gal” pochodzi z hebrajskiego. Pisał też o Galach jako pierwszych ludziach na ziemi ${ }^{80}$. Le Fèvre de La Boderie spopularyzował, zwłaszcza wśród mniej wymagającej publiczności, tezy Le Marie'a de Belges i Postela ${ }^{81}$.

W XVI stuleciu doszło do zdyskredytowania mitu o trojańskim pochodzeniu Francuzów zarówno wśród uczonych, jak i na dworze, a co więcej - wśród opinii publicznej. W kwestii mitu pochodzenia wypowiedział się Jean Bodin (1530-1590). Był krytyczny wobec trojańskiej wersji opowieści, ale zaprzeczał także germańskiemu pochodzeniu Franków. Historyk ten odwoływał się do łacińskiej, czyli rzymskiej kultury i Galii jako prowincji Rzymu ${ }^{82}$. Z kolei w 1579 roku w Recueil des Antiquités gauloises et françaises Claude Fauchet (1530-1602) ,wykazał bezpodstawność legendy o trojańskim pochodzeniu Franków"s3.

W latach 1560-1580 dokonało się upowszechnienie mitu galijskiego ${ }^{84}$, jednak i on spotkał się z krytycznym przyjęciem. Nauczyciel Pasquiera François Hotman (1524-1590) w 1573 roku wydał kontrowersyjną pracę La Gaule francoise (Francogallia). Autor odrzucił Francjona jako postać historyczną, bo był on poświadczony tylko przez poetów, a nie historyków ${ }^{85}$. Hotman uznawał, że Francuzi są jednym z kilku plemion germańskich, które pokonały Rzymian - a nie Galów, jak twierdził Rhenanus ${ }^{86}$. To zupełnie nowa wizja przeszłości, gdyż wcześniej z całą mocą francuscy pisarze odcinali się od niemieckich początków. W latach siedemdziesiątych XVI wieku katoliccy historycy (Jean du Tillet czy Jean de Serres) sprzeciwiali się jednak pochodzeniu od Germanów, na co miały wpływ współczesne spory religijne i pozycja protestantów, wszak reformacja zrodziła się na gruncie niemieckim ${ }^{87}$.

W relacji Hotmana Michel Foucault zauważył inny interesujący wątek - problem władzy. Galowie sprzeciwili się rzymskiemu imperium, a „bracia Germanie” pomogli im się wyzwolić. Wówczas Galowie i Germanie utworzyli jeden naród, stworzyli suwerenną władzę ludu wybieraną przez tych pierwszych na Polach Marsowych - tam dokonywano elekcji władcy. W przypadku niezadowolenia z rządów władcy społeczeństwo odbierało mu koronę. Wprowadzając taki opis na karty dzieła historycznego, Hotman dawał możliwość przeciwstawienia się współczesnej mu monarchii francuskiej dążącej ku rządom absolutnym ${ }^{88}$. Siłą i legitymacją oporu przeciw

80 C.-G. Dubois, Celtes et Gaulois..., s. 85-86.

${ }^{81}$ Ph. Des an, op. cit., s. 283. Szerzej o tym dziele: R.E. A sher, op. cit., 156-167.

82 B.L.O. Richter, op. cit., s. 125-126.

83 A. Grabski, op. cit., s. 188.

84 C.-G. Dubois, Celtes et Gaulois..., s. 89-101. Wydano m.in. Stephana Forcatula De Gallorum Imperio et philosophia libri septem (1579), Noëla Taillepieda L'Histoire de l'estat et république de Druides, Eubages, Sarronides, Bardes, Vacies Ancien François, Gouverneurs et païs de la Gaule, depuis le deluge universel jusques à la venuë de Jesus Christi en ce monde (1585).

85 B.L.O. Richter, op. cit., s. 127.

${ }^{86}$ G. Huppert, The Idea..., s. 81; M. Foucault, op. cit., s. 123; J. Koopman s, op. cit., s. 141.

87 C.-G. Dubois, Celtes et Gaulois..., s. 111.

88 M. Foucault, s. 124-125. 
despotyzmowi była tradycja. Pisarz ten zwracał uwagę na rządy wielu i monarchię tworzoną w wyniku elekcji, bo według niego to społeczność ma prawo decydować, komu powierza swe losy - tak jak u prapoczątków państwa. Postulaty reformacji ściśle łączyły się w tym wypadku z demokratyzacją ustroju ${ }^{89}$. Według George’a Hupperta po tej publikacji nie można już było odwoływać się do „średniowiecznej” opowieści o trojańskich początkach Francji ${ }^{90}$.

We francuskiej historiografii lat siedemdziesiątych XVI wieku dostrzegamy odrzucenie prawdziwości mitu o trojańskim pochodzeniu. Jean Papire Masson (15441611) jako pierwszy zakwestionował historyczność Faramunda ${ }^{91}$. Tak daleko nie posunął się François de Belleforest (1530-1583), historiograf Henryka III Walezego (1574-1589). W wydanym w 1579 roku dziele Les grandes annales, et histoire generale de France uznawał Faramunda za pierwszego króla francuskiego ${ }^{92}$, ale i ten pisarz nie zgadzał się na „szkodzące kłamstwa” na temat francuskiej etnogenezy, czyli pochodzenie od Hektora, Francjona i Trojańczyków ${ }^{93}$.

Do lat osiemdziesiątych XVI wieku odrzucenie francuskiego mitu początku było cechą charakterystyczną wszystkich uczonych oraz królewskich historiografów, bez względu na wyznanie czy „opcję polityczną" ${ }^{4}$. Na trojańskie pochodzenie nie zgadzał się również Lancelot Voisin de la Popelinière (1541-1608) w pracy wydanej u progu XVII stulecia - Histoire des histoires (1599) ${ }^{95}$.

Jak zauważa Roger Chartier, w tym czasie przeszukiwanie archiwów, pasja filologiczna i krytyka dokumentów razem z interpretacją historii prawa miały legitymizować monarchię absolutną oraz harmonijnie łączyć ją z erudycją i z ideą historii, której celem było racjonalne zrozumienie ludzkiej aktywności ${ }^{96}$. Należy z całą mocą podkreślić, że mit trojański o pochodzeniu Francuzów był użyteczny nie tylko dla władców, lecz także dla społeczeństwa, poszczególnych regionów i miast, które rościły sobie prawo do antycznych korzeni ${ }^{97}$. W XII wieku opowieść o przodkach trojańskich trafiła do szerszego odbiorcy ${ }^{98}$. Już nie tylko panujący powoływali się na pochodzenie z Troi, robiła to także szlachta, zwłaszcza wielkie rody. Pod koniec średniowiecza większość z nich uważała się za mających bezpośrednich przodków w antycznych Trojańczykach ${ }^{99}$. Nie przeszkadzał brak dowodów, wystarczały

89 J. Koopmans, op. cit., s. 137.

90 C.-G. Dubois, Celtes et Gaulois..., s. 111.

91 Por. K. Pomian, Przeszłość jako przedmiot wiedzy, s. 66, przyp. 114.

92 B.L.O. Richter, op. cit., s. 124.

93 G. Huppert, The Idea..., s. 83; R.E. Asher, op. cit., s. 26-27; B.L.O. Richter, op. cit., s. 123 in.

94 G. Huppert, The Idea..., s. 83; R.E. A sher, op. cit., s. 184 i n.

95 L. Voisin de La Popelinière, Histoire des Histoires, Paris 1599, s. 49-136.

96 R. Chartier, 1677 - Historiography in the Age of Absolutism [w:] A New History of French Literature, ed. D. Hollier, cooperation H. Bloch, P. Brooks, J. De Jean, B. Johnson, Ph.E. Lewis, Nancy K. Miller, F. Rigolot, N.J. Vickers, ed. 3, Cambridge, MA-London 2001, s. 348-349.

${ }_{97}$ J. Poucet, op. cit., s. 75. Zob. także rozszerzoną wersję tego artykułu: http://bcs.fltr.ucl.ac.be/ FE/05/anthenor2.html (dostęp: 1.01.2018).

98 C. Beaune, L'utilisation politique..., s. 332.

99 Ibidem, s. 333. 
wyobraźnia i mit państwowy. Średniowieczna arystokracja nie czuła się potomkami pokonanych przez Juliusza Cezara Galów. Szlachta francuska uznawała się za Franków, którzy podbili galijskie plemię, co na lata zapewniało królowi i arystokracji władzę. W końcu średniowiecza mit o trojańskim pochodzeniu stał się wspólną genealogią szlachecką, gwarantując jedność narodu i jego rangę wobec innych, co stanowi fundamentalną funkcję mitu etnogenetycznego. Od XIII stulecia mit o trojańskim pochodzeniu konsolidował społeczność ${ }^{100}$. W XV wieku społeczeństwo francuskie wierzyło w opowieść etnogenezy spod Troi, bo idealnie dopasowano ją do historii. Mniejsze znaczenie w obliczu jej masowego odbioru miała prawdziwość mitu. Był po prostu potrzebny w danej chwili, więc go podtrzymywano. Należy się zgodzić $\mathrm{z}$ tezą, że dał on Francji jedność narodową i państwową ${ }^{101}$.

Mit odnoszący się do Galów, powstały w XVI wieku, pełnił inną funkcję - wyrażał frustrację Francuzów w odniesieniu do supremacji kulturowej Włochów. Pozwalał im odnaleźć argumenty przeciwko łacińskiej dominacji. Zadawano sobie pytanie: skoro Francuzi istnieli przed Włochami, to po co używać języka łacińskiego? ${ }^{102}$ Zaczęto też ,powracać” do dawnych obyczajów czy ubierać się à la gauloise - na przykład przekłuwać uszy, jak niegdyś robili to Galowie ${ }^{103}$. Badacze zwracają uwagę, że z jednej strony idee renesansu służyły uniwersalizmowi, z drugiej jednak strony koniec XVI wieku to czas wyodrębniania się kultur narodowych ${ }^{104}$. Philippe Desan (nad wyraz śmiało) uznaje wręcz, że właśnie wówczas Francja miała wszystkie elementy „narodowe”. Regionalne różnice oraz mentalność późnego średniowiecza i wczesnego renesansu teraz ustąpiły miejsca jedności kulturowej - nie było już Normandów, Gaskończyków, Brytonów, lecz Francuzi ${ }^{105}$.

Po 1600 roku rozpoczęła się walka na pióra, z początkami narodu jako tematem przewodnim, choć stanowiły one problem dla samych pisarzy. Scipion Dupleix w $\mathrm{Hi}$ stoire générale de France (1621) przyją, że Frankowie, przybywając do Galii, mieli już rząd i przywileje społeczne, a zatem władza królów elekcyjnych była ograniczona. Czy takim stwierdzeniem Dupleix domagał się władzy dla ludu, sankcjonując to powrotem do tradycji antycznej? Pisarz ten stwierdzał, że dopiero gdy próbowano podbić Galię, Frankowie wybrali swego dowódcę Faramunda ${ }^{106}$. Historyk podkreślił, że Faramund to pierwszy suwerenny król panujący nad wszystkimi narodami frankijskimi i fundator monarchii francuskiej ${ }^{107}$. Był on potrzebny narodowi, ponieważ wówczas naród bez absolutnego władcy nie zrealizowałby swoich celów. Ponadto Faramund zjednoczył plemiona frankijskie w jeden naród - francuski. Dupleix

100 P. Morawki, op. cit., s. 68.

101 A. Bossuat, op. cit., s. 197. Warto jednak zwrócić uwagę, że Francja nie była jednolita. O Bretanii, regionie pogranicza, gdzie ścierały się mity brytyjskie, frankijskie i celtyckie, zob. J. Rio, op. cit., passim.

102 Ph. Desan, op. cit., s. 283.

103 Ibidem, s. 284.

104 C.-G. Dubois, Celtes et Gaulois..., s. 21.

105 Ph. Desan, op. cit., s. 288. Z tezą Desana można polemizować, biorąc pod uwagę istniejące we Francji partykularyzmy lokalne do czasów Wielkiej Rewolucji.

106 M. Yardeni, op. cit., s. 91; Ch. Gre11, op. cit., s. 82-83.

107 M. Yardeni, op. cit. s. 92. 
tłumaczył więc absolutyzm pierwszego władcy koniecznością obrony państwa, usprawiedliwiając taki ustrój tylko w określonych warunkach, czego liczne przykłady dawała tradycja antyczna.

Problem opowiedzenia się po którejś stronie w kwestii prawdziwości (a może już tylko wiarygodności) mitycznej opowieści widać w kolejnych pracach. Jezuita Jean-Étienne Tarault w Annales de France (1635) przedstawił wątpliwości czy wręcz otwartą krytykę szesnastowiecznych pisarzy w kwestii mitu pochodzenia, ale zaprzeczył, jakoby Frankowie zaliczali się do plemion germańskich ${ }^{108}$. W 1643 roku François de Mézeray (1610-1683) w Histoire de France depuis Faramond... twierdził zaś, że opowieść o trojańskim pochodzeniu jest oparta na faktach ${ }^{109}$. W XVII wieku liczyło się właściwie jedno stwierdzenie - przodkowie Francuzów nie musieli być Trojańczykami, ważne, by nie byli Germanami ${ }^{110}$. Zadedykowana Ludwikowi XIII (1610-1643) praca Taraulta służyła królewskiej propagandzie - przede wszystkim zaprzeczającej germańskiemu pochodzeniu Franków. W czasie panowania Ludwika XIII i Ludwika XIV (1643-1715) dominującą wersją pochodzenia pozostawał mit o pochodzeniu trojańskim ${ }^{111}$ - legitymujący współczesną suwerenność państwa. Rządy i kurs polityki europejskiej prowadzonej przez kardynała Richelieu i Ludwika XIV nie mogły się wpisywać $\mathrm{w}$ dawne konotacje z Germanami, dlatego od lat trzydziestych XVII wieku reaktywowano trojański mit o pochodzeniu lub - jeszcze częściej i dobitniej - pisano o Galach jako pierwotnych mieszkańcach tych ziem. W świetle tej koncepcji Galowie dopiero potem stali się Frankami i Germanami.

Idea pochodzenia służąca władcom francuskim zaczęła tracić popularność w 1714 roku, gdy uczony Nicolas Fréret wydał pracę O pochodzeniu Francuzów oraz o ich urzadzeniu się w Galli (De l'origine des Français et de leur établissement dans la Gaule). Udowadniał w niej, że Frankowie mają pochodzenie germańskie, czym „zasłużył” na trzymiesięczny pobyt w Bastylii. W XVIII stuleciu etnogeneza zajmowała Henriego hrabiego de Boullainvilliers (1658-1722), Jeana-Baptiste'a Du Bois (1670-1742), Monteskiusza (1689-1755), Gabriela Bonnota de Mably'ego (17091785) czy księdza Emmanuela-Josepha Sieyèsa (1748-1836) ${ }^{112}$. Rewolucja francuska wcale nie oznaczała końca mitu o trojańskim pochodzeniu Francuzów. Jeszcze w XIX wieku ${ }^{113}$, w czasach panowania Ludwika Filipa I (1830-1848), ponownie wydawano publikacje na temat Faramunda. Jacques Augustin Thierry (1795-1856),

108 Szerzej o idei mówiącej o tym, że Francuzi są plemieniem germańskim, zob. w: G. Huppert, The Idea ..., rozdz. The Origin of the Nation, s. 72-87. Rozdział ten został także w całości opublikowany jako: The Trojan Franks and Their Critics, „Studies in the Renaissance” 1965, vol. 12, s. 227-241.

109 G. Huppert, The Idea..., s. 84.

110 Ibidem, s. 74.

111 J. Poucet, op. cit., s. 81.

112 Szerzej zob. A.F. Grabski, op. cit., s. 326-329.

113 Por. obszerny artykuł na ten temat, prezentujący etnogenetyczny mit Francuzów w historiografii od starożytności do wybuchu I wojny światowej, skupiający się jednak przede wszystkim na XIX w.: K. Pomian, Francs et Gaulois [w:] Les Lieux de mémoire, t. 2, ed. P. Nora, Paris 1997, s. 2245-2300. Analizę mitu pochodzenia jako mitu narodowego na przestrzeni wieków, głównie w XIX stuleciu, przeprowadziła także S. Citron, Der Nationalmythos in Frankreich [w:] Politische Mythen und Rituale in Deutschland, Frankreich und Polen, hrsg. v. Y. Bizeul, Berlin 2000, s. 43-57. 
sekretarz Henriego de Saint-Simona (1760-1825), wykorzystywał opowieść do głoszenia swoich liberalnych poglądów. W micie galijskim doszukiwał się źródeł władzy i praw ludu, zatem w jego ujęciu był to mit założycielski stanu trzeciego ${ }^{114}$.

$* * *$

Historia mitu o trojańskim pochodzeniu Francuzów pokazuje, w jak różny sposób można wykorzystywać, wydawałoby się, tę samą opowieść w różnych celach: politycznych, społecznych, a nawet religijnych. Niezmienną wartością w historiografii zarówno średniowiecznej, jak i nowożytnej jest odniesienie się do wojny trojańskiej w poszukiwaniu przynależności do antycznej kultury, nakreślenia waleczności potomków - początkowo tylko wojowników, potem całego rycerstwa. Mit o trojańskim pochodzeniu Francuzów jest przykładem dziedzictwa chwały, pokrewieństwa wspaniałego i użytecznego, które gwarantowało niepodległość, wzrost dostatku i harmonii. Elementem podstawowym tej harmonii jest zjednoczenie ludności dzięki jej przodkom ${ }^{115}$. Integracja społeczeństwa to podstawowa funkcja mitu etnogenetycznego.

Potrzebę weryfikacji mitu, dostosowania jego treści do bieżących potrzeb Jan Assmann nazywa „mitomotoryką”. We francuskiej opowieści etnogenetycznej widać ją bardzo wyraźnie. Od trojańskich przodków wywodzono szlachectwo, a także fundament legislacyjny - prawo salickie ${ }^{116}$. Legitymowano (dzięki tradycji) współczesny ustrój lub dokonywano zmian w obrębie mitu, aby zakwestionować absolutyzm monarchy. Trojańscy Frankowie mieli organizować rady i zgromadzenia, na których dyskutowano sprawy, które ich zajmowały. W ten sposób legitymizowano potrzebę reprezentacji stanowej w ramach współczesnego ustroju społecznego. Faramund zaś uzasadniał ideę elekcyjności władcy ${ }^{117}$. Trojańskie motywy wykorzystywano nawet w dworskim ceremoniale - w czasie panowania Karola IX dekoracją uroczystego wjazdu królewskiego w 1571 roku była scena z udziałem Francjona i Faramunda, mająca symbolizować trojańskie pochodzenie władcy ${ }^{118}$.

Mit trojański odegrał też niezwykle istotną rolę we francuskiej polityce zagranicznej. W sporach z Anglią, Świętym Cesarstwem Rzymskim i papiestwem opowieść trojańska dostarczała argumentów historycznych i propagandowych przez kilka stuleci.

114 S. Citron, La construction du mythe national, s. 20 i n.

115 M.-B. Bruguière, op. cit., s. 55.

116 Por. wspomnienie Faramunda jako twórcy prawa salickiego w dramacie Henryk $V$ Williama Szekspira.

117 J. Koopmans, op. cit., s. 137.

118 M.-B. Bruguière, op. cit., s. 73. 


\section{BIBLIOGRAFIA}

\section{Źródła}

Dębołęcki (Dembołęcki) W., O tym, że najdawniejsze w Europie jest królestwo polskie, a język słowieński pierwotnym językiem świata [w:] Filozofia i myśl spoteczna XVII wieku, cz. 1, wybór, oprac., wstęp Z. Ogonowski, Warszawa 1979, s. 145-164.

Voisin de La Popelinière L., Histoire des Histoires, Paris 1599.

\section{Opracowania}

Adolph A., Brutus of Troy and the Quest for the Ancestry of the British, Barnsley 2015.

Asher R.E., National Myth in Renaissance France: Francus, Samothes and the Druids, Edinburgh 1993.

Assmann J., Pamięć kulturowa. Pismo, zapamiętywanie i polityczna tożsamość w cywilizacjach starożytnych, tłum. A. Kryczyńska-Pham, red. R. Traba, Warszawa 2008.

Beaune C., L'utilisation politique du mythe des origines troyennes en France à la fin du Moyen Âge [w:] Lectures médiévales de Virgile. Actes du colloque de Rome (25-28 octobre 1982), Rome 1985, s. 331-355.

Beaune C., Naissance de la nation France, Paris 1985.

Bizzocchi R., Genealogie incredibili. Scritti di storia nell'Europa moderna, Bologna 1995.

Bossuat A., Les origines troyennes : leur rôle dans la littérature historique au XVe siècle, „Annales de Normandie” 1958, 8 année, nº 2, s. 187-197.

Branny A., Trojanie i król Artur w angielskiej świadomości historycznej do XVIII wieku, „Historyka. Studia Metodologiczne” 1986, t. 16, s. 3-20.

Brinkley R.F., Arthurian Legend in the Seventeenth Century, London 1967.

Bruguière M.-B., Mythes de fondation et mission de la France : la légende troyenne [w:] L'influence de l'antiquité sur la pensée politique européenne (XVI-XX'me siècles), dir. par et préf. M. Ganzen, Aix-en-Provence 1996, s. 51-75.

Chartier R., 1677 - Historiography in the Age of Absolutism [w:] A New History of French Literature, ed. D. Hollier, cooperation H. Bloch, P. Brooks, J. De Jean, B. Johnson, Ph.E. Lewis, N.K. Miller, F. Rigolot, N.J. Vickers, ed. 3, Cambridge, MA-London 2001, s. 345-350.

Citron S., Der Nationalmythos in Frankreich [w:] Politische Mythen und Rituale in Deutschland, Frankreich und Polen, hrsg. v. Y. Bizeul, Berlin 2000, s. 15-57.

Citron S., La construction du mythe national [w:] Histoire de France, mythes et réalités. Quelle place pour les peuples et les minorités? Quelle place pour l'Europe?, dir. S. Citron, Ch. Guyonvarc'h, Y. Plasseraud, Toulouse 1995, s. 17-24.

Cohen P., In Search of the Trojan Origins of French: The Uses of History in the Elevation of the Vernacular in Early Modern France [w:] Fantasies of Troy: Classical Tales and the Social Imaginary in Medieval and Early Modern Europe, eds. A. Shepard, S.D. Powell, Toronto 2004, s. 63-80.

Desan Ph., Nationalism and History in France during the Renaissance, „Rinascimento. Rivista dell'Instituto Nazionale di Studi sul Rinascimento", seconda serie, vol. XXIV, Firenze 1984, s. 261-288. 
Dubois C.-G., Celtes et Gaulois au XVI siècle, le développement littéraire d'un mythe nationaliste, Paris 1972.

Dubois C.-G., "Nos ancêtres les Gaulois». Le développement d'un mythe des origines nationales au $16^{e}$ siècle [w:] Nos ancêtres les Gaulois, dir. P. Viallaneix, J. Ehrard, Clermont-Ferrand 1982, s. 18-35.

Eckhardt A., Sicambria, capitale légendaire des Français en Hongrie [w:] De Sicambria a Sans-Souci. Histoires et légendes franco-hongroises, Paris 1953, s. 11-51.

Eckhardt A., Sicambria, capitale légendaire des Français en Hongrie, „Revue des Études Hongroises" 1928, vol. 6, s. 166-197.

Foucault M., Wyktad z 11 lutego 1976 r. [w:] M. Foucault, Trzeba bronić społeczeństwa. Wyktady w Collège de France, 1976, thum. M. Kowalska, Warszawa 1998, s. 119-143.

Geary P.J., The Myth of Nations: The Medieval Origins of Europe, Princeton 2002.

Gosman M., Alain Chartier : le mythe romain et le pouvoir royal français [w:] Entre fiction et histoire : Troie et Rome au Moyen Age, éds. E. Baumgartner, L. Harf-Lancner, Paris 1997, s. 161-176.

Grabski A.F., Dzieje historiografii, Poznań 2011.

Grandazzi A., La Troie rêvée des Romains : quelles leçons pour l'Europe contemporaine? [w:] Le mythes de fondation et l'Europe, dir. B. Bernabé, O. Camy, Dijon 2013, s. 37-53.

Grell Ch., Guerres généalogiques et identités nationales : la France et l'Europe, „Revista de Historiografía" 2011, nr 15, s. 77-89.

Huppert G., Naissance de l'histoire en France : les "Recherches 》 d'Estienne Pasquier, „Annales. Economies, Sociétés, Civilisations” 23e année, 1968, nr 1, s. 69-105.

Huppert G., The Idea of Perfect History: Historical Erudition and Historical Philosophy in Renaissance France, Chicago-London 1970.

Huppert G., The Trojan Franks and Their Critics, „Studies in the Renaissance” 1965, vol. 12, s. 227-241.

Kendrick T.D., British Antiquity, New York-London 1970.

Koopmans J., À l'ombre de Pharamond: la royauté élective, „Cahiers de Recherches Médiévales et Humanistes" 2010, nr 20, s. 135-143.

Kowalski J., Loba A. i M., Prokop J., Dzieje kultury francuskiej, Warszawa 2007.

Melville G., Troja: Die integrative Wiege europäischer Mächte im ausgehenden Mittelalter [w:] Europa 1500. Integrationsprozesse im Widerstreit: Staaten, Regionen, Personenverbände, Christenheit, hrsg. v. F. Seibt, W. Eberhard, Stuttgart 1987, s. 415-432.

Morawski P., Mit o trojańskim pochodzeniu Franków w historiografii średniowiecznej Francji, „Przegląd Humanistyczny” R. 51, 2007, nr 5, s. 55-70.

Orzeł J., Historia - tradycja - mit w pamięci kulturowej szlachty Rzeczypospolitej w XVIXVIII wieku, Warszawa 2016.

Pinsard M., Nos ancêtres les Francs, [b.m.w.] 2013.

Pomian K., Francs et Gaulois [w:] Les Lieux de mémoire, vol. 2, ed. P. Nora, Paris 1997, s. $2245-2300$.

Pomian K., Przeszłość jako przedmiot wiary. Historia i filozofia w myśli średniowiecza, wyd. 2 rozszerzone, Warszawa 2009,

Pomian K., Przeszłość jako przedmiot wiedzy, wyd. 2 poprawione, Warszawa 2010.

Poucet J., L'origine troyenne des peuples d'Occident au Moyen Âge et à la Renaissance. Un exemple de parenté imaginaire et d'idéologie politique, „Les Études Classiques” 2004, vol. 72, s. 75-107.

Pysiak J., Pogańska przeszłość Franków w świetle kilku kronik francuskich z czasów Filipa Augusta i Ludwika Świętego, ,Kwartalnik Historyczny” 110e année, 2003, nr 1, s. 5-28. 
Richter B.L.O., Trojan or Merovingians? The Renaissance Debate over the Historical Origins of France [w:] Mèlanges à la mémoire de Franco Simone, vol. 4, Geneva 1983, s. 111-134.

Rio J., Mythes fondateurs de la Bretagne. Aux origines de la celtomanie, Rennes 2000.

Samsonowicz H., Mit „początku” w oczach historyka, „Przegląd Humanistyczny” 1996, nr 1, s. 47-52.

Szacka B., Czas przeszty - pamięć - mit, Warszawa 2004.

Wathelet P., Le mythe d'Énée dans l'épopée homérique. Sa suivre et son exploitation poétique [w:] Mythe et politique, éds. F. Jouan, A. Motte, Paris 1990, s. 287-296.

Wulf K., Troja - Metamorphosen eines Mythos. Französische, englische und italienische Überlieferungen des 12. Jahrhunderts im Vergleich, Berlin 2009.

Yardeni M., Enquêtes sur l'identité de la "nation France », de la Renaissance aux Lumières, Seyssel 2004.

Zawadzka A., Mit etnogeniczny jako źródło w studiach nad stereotypem. Mity o pochodzeniu Gallów [w:] Grecy, Rzymianie $i$ ich sasiedzi, red. K. Nawotka, M. Pawlak, współpr. A. Paluchowski, A. Woj ciechowska, Wrocław 2007, s. 279-297. 